\title{
Surfaces
}

\section{Identity without an Entity}

Roundtable 2

\section{Alessandra Tanesini}

Volume 7, 1997

\section{LE FÉMINISME HORS DE LUI-MÊME}

FEMINISM BESIDE ITSELF

URI : https://id.erudit.org/iderudit/1064806ar

DOI : https://doi.org/10.7202/1064806ar

Aller au sommaire du numéro

Éditeur(s)

Les Presses de l’Université de Montréal

ISSN

1188-2492 (imprimé)

1200-5320 (numérique)

Découvrir la revue

Citer cet article

Tanesini, A. (1997). Identity without an Entity: Roundtable 2. Surfaces, 7.

https://doi.org/10.7202/1064806ar d'utilisation que vous pouvez consulter en ligne. 


\title{
Identity without an Entity Roundtable 2
}

\author{
Alessandra Tanesini \\ University of Wales \\ Cardiff
}

Surfaces Vol. VII.107 (v.1.0A - 26/06/1997) - ISSN:

1188-2492

Copyright for texts published in Surfaces remains the property of authors. However, any further publication should be accompanied by an acknowledgement of Surfaces as the place of initial publication.

The question of identity seems to have become the aporia of contemporary feminist thinking[ $\underline{\mathbf{1}}$ ]. It appears that some notion of the identity of "woman" is required to propel political action within the feminist movement, but, on the other hand, the logic of identity claims requires that boundaries are drawn to exclude some from the domain of that identity.

I believe that what I present above is a false dilemma that acquires the appearance of an aporia through the shared metaphysical assumptions which sustain both its alternatives. In this paper, I briefly discuss both alternatives to bring forth the metaphysic upon which they are predicated, and attempt to offer a way out of this dichotomy. I claim there 'is' an identity of 'woman,' but in a metaphysical sense, this is an identity without an entity.

It is indeed peculiar that feminism has reinscribed within itself the traditional philosophical attitude that requires a settlement of metaphysical questions, before thinking in the areas of politics and morality can proceed. Linda Alcoff's often-quoted paper "Cultural Feminism versus Post-Structuralism: The Identity Crisis in Feminist Theory"[ $\underline{\mathbf{2}}$ ] exemplifies this move: where one stands on the issue of the identity of "woman" is taken to define the 
sort of feminism one subscribes to. This move limits and antagonizes the discourse of feminist theory: limits because it prescribes that the metaphysical issue of gender identity always be present; antagonizes because it aims at providing unique identity conditions for feminist theories and for sorting thinkers into camps.[ $\underline{\mathbf{3}}$ ]

The issue of gender identity is thus given a foundational role in theory: it becomes both that which needs (in a temporal sense) to be sorted out first, and that which provides a justification for the theory that is taken as stemming from it. Theories are built either on the metaphysics of the identity of 'woman', or, on the flip side of the same coin, the metaphysics of the impossibility of gender identity.

The result of this foundationalist move is that the question of 'Woman' is located outside the political sphere as that which gives validity to political thought.[ $\underline{4}$ ] It should already be clear that something must have gone amiss. This dilemma of gender identity that troubles feminism is an ethical and political dilemma; it concerns political and ethical choices. How could it be solved by a metaphysical claim that is taken to stand outside politics? It cannot, and a misconstrual of the issue of identity provides the appearance of a solution. The question of identity has to be construed as a question of the nature of the subject who, as agent, is capable of making choices. Subjectivity and identity become entangled in a relation of whole to part.[ $\underline{\mathbf{5}}$ ] Once this move is accomplished, the terrain of the available options is already mapped: we can either attribute or deny metaphysical reality to gender identity. And this first dichotomy generates a multiplicity of others.

For some, the metaphysical reality of gender is empirical; it is a matter of the essential features of actual women.[ $\underline{\mathbf{6}}$ ] For others it is a constitutive aspect of the 'self' which is a necessary condition for the possibility of empirical agency.[ 7 ] And yet, those who deny metaphysical reality to gender are compelled either to explain its apparent substance as an effect of prior discursive formations, [ $\underline{\mathbf{8}}$ ] or simply to explain it away.[ 9 ]

All these positions have the typical monolithic and formalistic character of metaphysical theories which assert, in the most abstract sense, what is and what is not. They all suggest that, at least in its most formal 
structure, the dilemma of identity politics can be solved once and for all, and in advance of political engagement. In a qualified sense this is true even of Judith Butler's approach, because, although she deplores the attempts to give in advance universal and specific content to the category of women,[ $1 \mathbf{1 0}]$ her position nevertheless construes the necessity of identity politics as a necessity of false belief. Identity statements, she claims, are needed for political reasons. It is important to make them and to multiply their meanings, but we must understand that these claims function as performatives. That is, they are metonymies in the Nietzschean sense, whereby language produces effects that it then presents as if they were its causes. For Butler, there is no gender behind the discourse of gender. However, the political necessity she claims for statements of identity is predicated on the (false) belief in the pre-existence of gender, since she holds that this political necessity is a consequence of the inevitability of engagement with representational politics.[ $\underline{11}$ ]

Butler is right to claim that we cannot and should not fix the content of the category "woman," but she commits a mistake in her attempt to fix the logical structure of gender attributions as performatives. By doing so, she produces another metaphysical account of gender as an attribute, intrinsic or relational, of persons.

It is this attributive account of gender that is shared by all the metaphysical options mentioned above. It is not relevant to the issue at hand whether persons are believed to pre-exist discourse, or whether they are taken to be constituted by linguistic formations; in either case, gender is viewed as an attribute; something a person has (or comes to have). Furthermore, in both cases discourse about gender is taken to mirror reality, either by describing it or by performatively producing it. Hence, both foreclose the possibility of a gap, a slack, between talk of "woman" and actual women. Moreover, both accounts presuppose that the metaphysics of the attributive character of gender stands outside politics. For Butler, of course, each performative constitution of gender is already within the realm of politics, but the formal claim that gender is performatively constituted functions as a metaphysical foundation for political thought.

When identity claims are understood attributively (in either descriptive or performative fashion), the question of identity politics becomes theoretical rather than practical, and a question to be settled in metaphysical terms. Furthermore, given the undoubted importance of 
identity politics to feminist theory, this theory itself becomes, like much traditional philosophy, defined by its solutions to ontological questions. The dilemma between humanistic and anti-humanistic politics, played out between many feminist thinkers, is at least in part the result of the belief that we need our metaphysics in place before practical reason can do any work.[ 12 ]

The dilemma of identity politics with which I started this essay is a practical dilemma, one that can be addressed only in specific circumstances and which can receive only specific answers: at times, the situation will warrant identity claims, at other times it will not. The answers, however, will never be purely a matter of political expediency, although expediency is not unimportant. Rather, it will be a matter of articulating the situation in the context of a sustained dialogue about the justification of ethical demands.[ $\underline{13}$ ]

One might object that what I have outlined above is not a real option since there is no alternative to the attributive articulation of the notion of gender. A non-attributive account of gender is possible; consequently I provide below an outline of such an account.[ $\underline{\mathbf{1 4}}$ ]

"Woman" is a normative term, and as such does not describe some pre-existent reality.[ 15 ] Normative claims are attempts to express a judgment about how we should develop those practices that constitute our form of life, our community. Some of these judgments amount to an endorsement of the status quo, others to an endorsement of change. Normative claims, of course, are only intelligible against a background of existing practices and discourses that enable some claims to be made and preclude the possibility of making others.

To make claims about "woman," to engage in identity politics, is to make a critical intervention concerning the norms that regulate women. These engagements with current normative discourse involve making explicit the fact that claims about "women" are always claims about what some individuals ought to be like, rather than about what they are like. This is the naturalising effect of language that Butler attempts to capture in her performative account.

These engagements also involve bringing to light at least some of the injustices inherent in current normative discourse about gender.[ $\underline{\mathbf{1 6}}$ ] To make this sort of claim is to invoke the notion of an identity for 'woman' without believing in a corresponding entity. It is not the case that discourse about "woman" reflects a pre-existing reality; 
nor is a substantive identity of "woman" produced by discourse. Language, of course, has effects: it changes our practices, changes aspects of our social reality. Nevertheless, to employ normative discourse about woman is not automatically to become complicit with the construction of gender as something that presents itself as preceding that which constructs it. One can talk, instead, of "woman," in order to have an effect on the norms implicit in a society, without one's language ever referring to a pre-existent or performatively created attribute.

There are dangers inherent in talk of this sort, since it aims to prescribe what women should be able to do. However, whether or not such normative claims are warranted or useful can be judged only within the context of their production. One should be suspicious of identity politics when it is used from a narrow perspective to prescribe how others should be. Nevertheless, we need not abandon altogether talk about identity since there is no other way to emend oppressive norms but by engaging with these norms and showing why they are not warranted. As long as we are aware that "woman" does not refer to an entity, identity claims can still be a useful weapon in the armory of feminists.

\section{NOTES}

1. I would like to thank all the other speakers at that conference for many interesting conversations.

2. Originally published in Signs: Journal of Women in Culture and Society, XIII (Spring 1988), pp. 405-436, it also appears in many anthologies.

3. I owe this point to Diane Elam.

4. A similar point is made by Judith Butler, Contingent Foundations, Feminist Contentions (New York: Routledge, 1995), p. 36.

$\underline{\mathbf{5}}$. I presuppose here that the question of subjectivity is a metaphysical question.

6. This is Carol Gilligan's position in In a Different Voice: Psychological Theory and Women's Development (Cambridge, MA: Harvard University Press, 1982). 
7. For example, Seila Benhabib, Situating the Self (Cambridge: Polity Press, 1992).

8. For example Judith Butler, Gender Trouble (New York: Routledge, 1990).

9. No one to my knowledge holds precisely this view except the fictional Butler created by some of her critics.

10. See Butler, Contingent Foundations, p. 50 .

11. Butler, p. 49.

12. Both on the importance of the gap, and on practical reason see Drucilla Cornell, What is Ethical Feminism? , Feminist Contentions (New York: Routledge, 1995).

13. This, of course, needs to be explained in detail. My concern here is with the possibility of an ethics which does not need to be grounded on theory.

14. I have discussed this account in detail in Whose Language? , Knowing the Difference, eds. Kathleen Lennon \& Margaret Whitford (London: Routledge, 1994), pp. 203-216.

15. On this, I believe, Butler would agree.

16. There might also be injustices which could not be even expressed in the normative discourse we employ here and now. It is nevertheless possible to change even the expressive capacity of our normative talk.

Accueil Surfaces | Table des matières | Recherche Surfaces Home Page | Table of Contents | Search

PUM | Livres | Revues | Publications électroniques | Vente et distribution 